
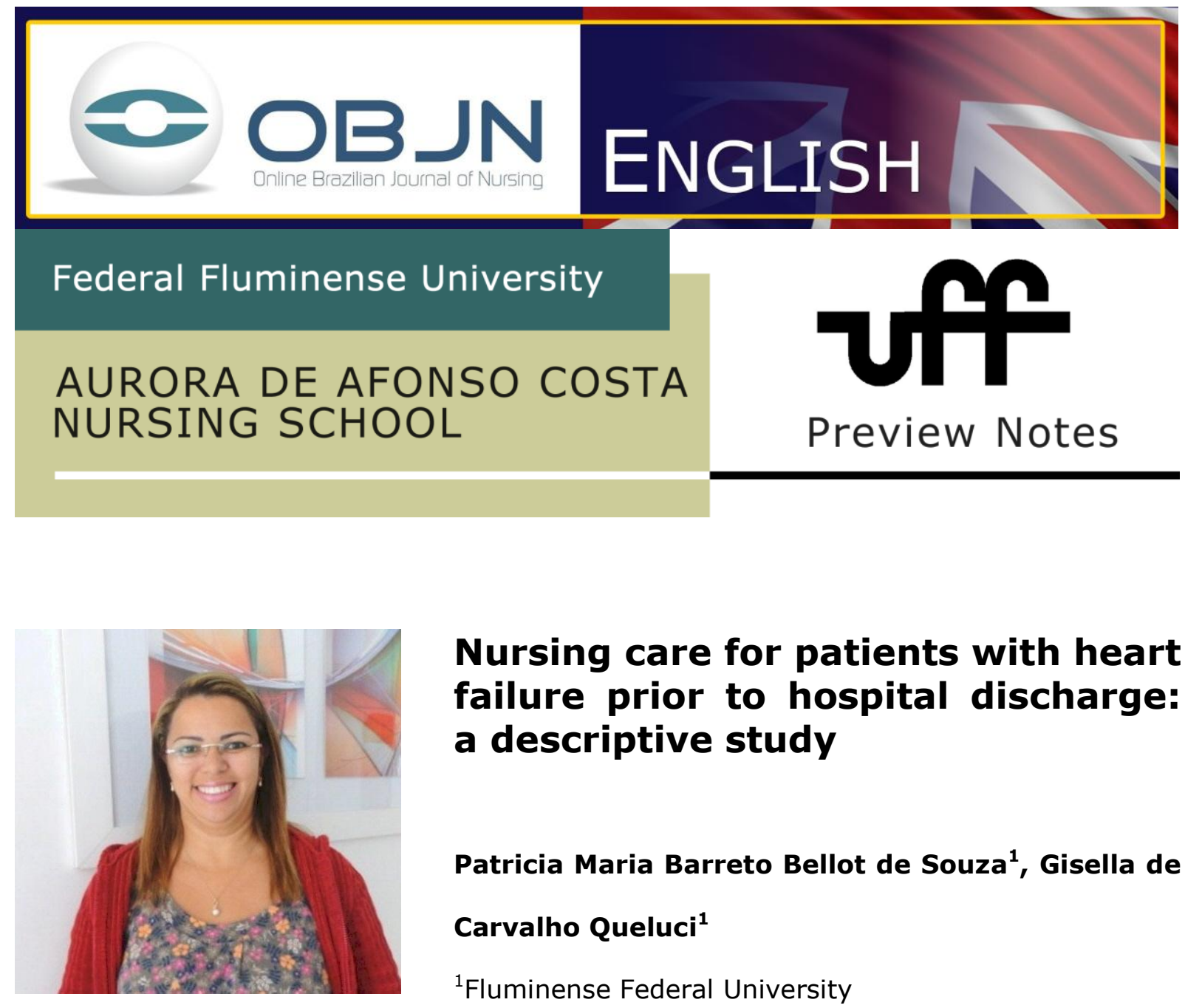

\title{
Nursing care for patients with heart failure prior to hospital discharge: a descriptive study
}

Patricia Maria Barreto Bellot de Souza ${ }^{1}$, Gisella de Carvalho Queluci ${ }^{1}$

${ }^{1}$ Fluminense Federal University

\begin{abstract}
This is a descriptive study which adopts a qualitative approach. It seeks to identify the profile of patients hospitalized with heart failure (HF) in a university hospital, and describes how nurses make use of nursing guidelines for the hospital discharge of these patients, and how they develop a specific nursing care plan for a patient with HF. The study scenario will be the Men and Women Medical Clinic Sectors of a federal public hospital in the state of Rio de Janeiro. The study will have as its subjects, patients with HF hospitalized in these clinics and the nurses who provide care for them. This research will meet the requirements of Resolution 196/96 of the CNS and Ethics Committee (CEP) of the Institution.
\end{abstract}

Keywords: nursing Care, patient discharge; heart failure. 


\section{PROBLEM AND SIGNIFICANCE OF THE SITUATION}

Hospital discharge is the moment at which the hospitalized patient is transferred from hospital care. The patient receives guidance on the specific care to be performed in the environment outside the hospital and/or the ambulatory clinic. Therefore, it is necessary to carefully assess the clinical condition of the patient in order to minimize readmissions. In view of these considerations, a proper planning of nursing care and the development of a care plan are essential, in order to present, in a clear and objective way, the actions of nurses and the guidelines that have been prepared to meet the main needs of the patient who is about to be discharged. Heart failure (HF) consists of a complex syndrome that is highly prevalent, especially in people over 65 . It is said that approximately $10 \%$ of HF patients progress to more severe forms of the disease, including patients who, despite the implemented clinical treatment, continue showing evidence of disease progression, unacceptable quality of life and high mortality rate in a year ${ }^{(1)}$. In Brazil, HF is the leading cause of the hospitalization of patients over 60 year within the Unified Health System (UHS) and represents $30 \%$ of hospitalizations related to the cardiovascular system. The annual cost of treatment is $\mathrm{R} \$ 200$ million $^{(2)}$. Thus, this study will contribute in that HF patients may receive the specific care of a multidisciplinary team, because, despite the treatment implemented in specialized clinics, there is still a percentage of patients with a picture of physical decompensation such as the development of edema, dyspnea and fatigue, as well as decompensation in the psychobiological balance in terms of anxiety, fear and depression due to chronic heart disease ${ }^{(3)}$.

\section{OBJECTIVES}

To identify the profile of patients hospitalized with HF at a university hospital; to describe how nurses undertake to fulfill the nursing guidelines as part of the hospital discharge process with regard to these patients; and to develop a plan with regard to specific nursing care for HF patient at discharge. 


\section{GUIDING QUESTIONS}

What is the profile of HF patients? How are the nursing guidelines carried out as part of the hospital discharge process for HF patients? What form should a specific discharge plan take for a HF patient?

\section{PREREQUISITES}

Patients with heart failure, hospitalized in the Cardiology Section of a Men and Women Medical Clinic, need guidelines with regard to hospital discharge related to pharmacological and non-pharmacological treatment, in order to ensure the quality of care provided at home.

\section{METHOD}

This is a descriptive study which will adopt a qualitative approach. This study will be carried out in the Cardiology Section of a male and female Medical Clinic in a federal hospital. The aim will relate to education, research and providing a service. The subjects of this study will be the HF patients hospitalized in these clinics and the nurses who provide assistance in the sectors mentioned above. For data collection purposes we shall use the technique of semi-structured interviews together with a nursing assessment tool for patients with HF. We will also undertake research into their medical records. In addition we will use an instrument containing open questions aimed at the nurses working in this sector. For the analysis and interpretation of the data we will triangulate these data, including the profile of the patients, nurses opinions and the analysis of the researcher, based on the content analysis method advocated by Bardin. With regards to the ethical aspects which will guide this research, it should be said that they are grounded in Resolution 196/96 of the National Health Council, with the approval of the 
Ethics and Research Committee of the School of Medicine/University Hospital Antonio

Pedro, on November 4, 2011 under opinion No 310/11

\section{REFERENCES}

1. Yoshimori DY, Cipriano Junior G, Mair V, Branco JNR, Buffolo E. Avaliação e seguimento em médio prazo em candidatos a transplante cardíaco submetidos a exercício de baixa intensidade. Rev Bras Cir Cardiovasc [serial in the internet]. 2010 Jul [cited 2011 Apr 26]; 25(3). Available from: http://www.rbccv.org.br/detalhe artigo.asp?id=1011

2. Malta DC, Cezário AC, Moura L, Morais Neto OL, Silva Junior JB. A construção da vigilância e prevenção das doenças não transmissíveis no contexto do Sistema Único de Saúde. Epidemiologia Serviços de Saúde [serial in the internet]. 2006 Jul [cited 2011 Apr 14]; 15(3): 47-65. Available from: http://portal.saude.gov.br/portal/arquivos/pdf/5artigo construcao cronicas.pdf

3. Correa LA, Santos I, Albuquerque DC. Nursing assessment: Research/Care through the sensible listening in the heart failure clinic. Online braz $\mathrm{j}$ nurs [serial in the internet] 2008 Jul [cited 2011 Set 14]; 7(1). Available from: http://www.objnursing.uff.br/index.php/nursing/article/view/j.1676$\underline{4285.2008 .1066 / 296}$

\section{Project Data}

Dissertation project of the Professional Master Program in Nursing of the Nursing School Aurora de Afonso Costa at Fluminense Federal University.

Teacher Advisor: Gisella de Carvalho Queluci.

Approval by the Research Ethics Committee of the School of Medicine/University Hospital Antonio Pedro, on November 4, 2011 under opinion No. 310/11. 